\title{
A Comparative Analysis of the Ultrastructure of Hydrocarbon-oxidizing Micro-organisms
}

\author{
By CHRISTINA C. L. SCOTT AND W. R. FINNERTY \\ Department of Microbiology, University of Georgia, Athens, Georgia 30602, U.S.A.
}

(Received 30 September 1975; revised 25 November 1975)

S UMMARY

The ultrastructure of a variety of micro-organisms was compared after growth on hydrocarbon and non-hydrocarbon substrates. Hydrocarbon-grown organisms were characterized by the presence of intracellular electron-transparent inclusions which in many cases appeared membrane-bound. With one exception, nonhydrocarbon-grown organisms did not contain electron-transparent inclusions. Insignificant amounts of poly- $\beta$-hydroxybutyric acid were produced by the hydrocarbon-grown micro-organisms. After growth on hydrocarbons, all the microorganisms had accumulated varying amounts of the respective unmodified hydrocarbon growth substrate.

\section{INTRODUCTION}

The ultrastructure of several micro-organisms has been reported following growth on hydrocarbon substrates. Two species of Arthrobacter and the yeast Candida utilis have been characterized by the presence of 'oxisomes' after growth in media containing butane or butanol as the sole carbon and energy source (Kormandy \& Wayman, I974). These electronopaque structures were surrounded by an electron-transparent area and were considered to represent sites of hydrocarbon oxidation. Methane-oxidizing bacteria have been shown to possess extensive and complex intracytoplasmic membranous structures generally not found in other Gram-negative bacteria (DeBoer \& Hazeu, 1972; Davies \& Whittenbury, 1970). Electron-opaque inclusions have been observed in two species of oil-degrading marine bacteria (Atlas \& Heintz, 1973). These inclusions stained positively with Sudan black B, a characteristic of stored lipids. A positive correlation has been reported in $C$. tropicalis pk233 between the development of microbodies, increased catalase activity and alkane oxidation (Osumi et al., 1975).

The fine structure of a hydrocarbon-oxidizing Acinetobacter sp. has been examined in detail after growth on long-chain paraffinic and olefinic hydrocarbons as sole carbon and energy sources (Kennedy et al., 1975; Kennedy \& Finnerty, 1975). The growth of this organism at the expense of the hydrocarbon substrates was characterized by two ultrastructural modifications, namely the cytoplasmic pooling of unmodified hydrocarbon and the specific induction of an intracytoplasmic membrane complex.

We have undertaken a comparative study to determine if hydrocarbon pooling, as demonstrated in Acinetobacter, represents a generalized phenomenon characteristic of hydrocarbon-oxidizing micro-organisms. Thin sections of a diverse group of microorganisms were examined after growth on hydrocarbon substrates. 
Table I. Hydrocarbon-oxidizing micro-organisms and culture conditions

\begin{tabular}{|c|c|c|c|c|c|c|}
\hline \multirow[b]{3}{*}{ Organism } & \multirow{2}{*}{\multicolumn{2}{|c|}{ Growth substrate }} & \multicolumn{2}{|c|}{$\begin{array}{l}\text { Culture } \\
\text { conditions }\end{array}$} & \multicolumn{2}{|c|}{ Culture age* } \\
\hline & & & & & & \\
\hline & Hydrocarbon & $\begin{array}{c}\text { Non- } \\
\text { hydrocarbon }\end{array}$ & $\begin{array}{l}\text { Hydro- } \\
\text { carbon }\end{array}$ & $\begin{array}{l}\text { hydro- } \\
\text { carbon }\end{array}$ & $\begin{array}{l}\text { Hydro- } \\
\text { carbon }\end{array}$ & $\begin{array}{l}\text { hydro- } \\
\text { carbon }\end{array}$ \\
\hline Acinetobacter sp. ноI-N & $\begin{array}{l}0.5 \%(v / v) \text { hexa- } \\
\text { decane }\end{array}$ & NBYE & $\begin{array}{l}28^{\circ} \mathrm{C} \text {, } \\
\text { shake }\end{array}$ & $\begin{array}{l}28^{\circ} \mathrm{C} \text {, } \\
\text { shake }\end{array}$ & $8 \mathrm{~h}$ & $6 \mathrm{~h}$ \\
\hline Pseudomonas sp. NP & Naphthalene vapours & NBYE & $30^{\circ} \mathrm{C}$ & $\begin{array}{l}30^{\circ} \mathrm{C} \text {, } \\
\text { shake }\end{array}$ & $5 \mathrm{~d}$ & $12 \mathrm{~h}$ \\
\hline Arthrobacter sp. 80 & $\begin{array}{l}\text { I.0\%(v/v) hexa- } \\
\text { decane }\end{array}$ & NBYE & $\begin{array}{l}30^{\circ} \mathrm{C} \\
\text { shake }\end{array}$ & $\begin{array}{l}30^{\circ} \mathrm{C} \text {, } \\
\text { shake }\end{array}$ & $36 \mathrm{~h}$ & $24 \mathrm{~h}$ \\
\hline Corynebacterium sp. & $\begin{array}{l}\mathrm{I} \cdot 0 \%(\mathrm{v} / \mathrm{v}) \text { hexa- } \\
\text { decane }\end{array}$ & NBYE & $\begin{array}{l}30^{\circ} \mathrm{C} \text {, } \\
\text { shake }\end{array}$ & $\begin{array}{l}30^{\circ} \mathrm{C} \text {, } \\
\text { shake }\end{array}$ & $36 \mathrm{~h}$ & $24 \mathrm{~h}$ \\
\hline $\begin{array}{l}\text { Mycobacterium album } \\
7 \mathrm{E} 4\end{array}$ & Hexadecane vapours & Nutrient agar & $30^{\circ} \mathrm{C}$ & $30^{\circ} \mathrm{C}$ & $7 \mathrm{~d}$ & $48 \mathrm{~h}$ \\
\hline $\begin{array}{l}\text { Mycobacterium vaccae } \\
\text { JOB5 }\end{array}$ & $\begin{array}{l}1.0 \%(v / v) \text { hexa- } \\
\text { decane }\end{array}$ & NYBE & $\begin{array}{l}30^{\circ} \mathrm{C} \\
\text { shake }\end{array}$ & $\begin{array}{l}28^{\circ} \mathrm{C} \text {, } \\
\text { shake }\end{array}$ & $48 \mathrm{~h}$ & $72 \mathrm{~h}$ \\
\hline Nocardia sp. 72 & $\begin{array}{l}1.0 \%(v / v) \text { hexa- } \\
\text { decane }\end{array}$ & NBYE & $\begin{array}{l}30^{\circ} \mathrm{C} \text {, } \\
\text { shake }\end{array}$ & $\begin{array}{l}28^{\circ} \mathrm{C} \\
\text { shake }\end{array}$ & $36 \mathrm{~h}$ & $20 \mathrm{~h}$ \\
\hline Nocardia rubra & $\begin{array}{l}1.0 \%(v / v) \text { hexa- } \\
\text { decane }\end{array}$ & NBYE & $\begin{array}{l}30^{\circ} \mathrm{C} \text {, } \\
\text { shake }\end{array}$ & $\begin{array}{l}28^{\circ} \mathrm{C} \text {, } \\
\text { shake }\end{array}$ & $36 \mathrm{~h}$ & $24 \mathrm{~h}$ \\
\hline Candida lipolytica Phaff & $\begin{array}{l}\mathrm{I} \cdot 0 \%(\mathrm{v} / \mathrm{v}) \text { hexa- } \\
\text { decane }\end{array}$ & NBYE & $\begin{array}{l}30^{\circ} \mathrm{C}, \\
\text { shake, } \\
\text { pH } 7.0\end{array}$ & $28^{\circ} \mathrm{C}$ & $36 \mathrm{~h}$ & $12 \mathrm{~h}$ \\
\hline Candida tropicalis & Tetradecane vapours & NBYE & $30^{\circ} \mathrm{C}$ & $30^{\circ} \mathrm{C}$ & $7 \mathrm{~d}$ & $24 \mathrm{~h}$ \\
\hline
\end{tabular}

* The organisms were harvested after three successive passes in the respective growth medium.

\section{METHODS}

Organisms and culture conditions. The micro-organisms used in the survey and the culture conditions employed are summarized in Table $\mathrm{I}$. The organisms were grown in a minimal salts medium of the following composition $\left(\mathrm{g} \mathrm{l}^{-1}\right):\left(\mathrm{NH}_{4}\right)_{2} \mathrm{SO}_{4}, 2 ; \mathrm{KH}_{2} \mathrm{PO}_{4}, 4 ; \mathrm{Na}_{2} \mathrm{HPO}_{4}, 4$; $\mathrm{MgSO}_{4} \cdot 7 \mathrm{H}_{2} \mathrm{O}, 0.2 ; \mathrm{CaCl}_{2}, 0.00 \mathrm{I} ; \mathrm{FeSO}_{4} \cdot 7 \mathrm{H}_{2} \mathrm{O}$, 0.00I, $\mathrm{pH} 7.8$; the medium was supplemented with hydrocarbon as specified in Table $\mathrm{I}$. The organisms grown in hydrocarbon vapours were streaked on to the surfaces of minimal salts agar plates containing hydrocarbonsaturated filter paper. The minimal salts medium was supplemented with either $0.8 \%(\mathrm{w} / \mathrm{v})$ nutrient broth plus $0.5 \%(\mathrm{w} / \mathrm{v})$ yeast extract (NBYE), or with nutrient agar. Variations to the above growth conditions are specified in Table $\mathrm{I}$.

The micro-organisms used were generously provided as follows: Pseudomonas sp. NP from Dr D. T. Gibson; Arthrobacter 80 and Nocardia 72 from Dr D. K. Button; Mycobacterium album $7 \mathrm{E} 4$ and $M$. vaccae JOB5 from Dr J. Perry; $C$. lipolytica Phaff from Dr A. Markovetz; C. tropicalis from Dr E. Azoulay; the other micro-organisms studied are carried in routine stock culture as hydrocarbon oxidizers in this laboratory.

Electron microscopy. The organisms were harvested at the culture age indicated in Table $I$ and fixed according to the procedure of Kellenberger, Ryter \& Sechaud (I958). The fixed cells were embedded in $\mathrm{I} \%(\mathrm{w} / \mathrm{v})$ Noble agar, cut into $\mathrm{I} \mathrm{mm}^{3}$ blocks, and stained en bloc in $0.5 \%(\mathrm{w} / \mathrm{v})$ uranyl acetate for $2 \mathrm{~h}$. The agar blocks were dehydrated through a graded series of ethanol-water mixtures followed by propylene oxide, and embedded in Epon 81 2 (Luft, I96I). 
Thin sections were cut with a diamond knife on a Reichert OMU-2 ultramicrotome and mounted on copper grids. The sections were stained with uranyl acetate followed by lead citrate (Reynolds, 1963) and examined in a Philips 200 electron microscope operated at $80 \mathrm{kV}$.

Analysis of intracellular hydrocarbon. Hydrocarbon-grown cells were harvested at the culture age specified in Table $\mathrm{I}$ and washed four times with the minimal salts medium which lacked $\mathrm{MgSO}_{4}$ and $\mathrm{CaCl}_{2}$. The washed cells were lyophilized, and a known quantity (15 to $30 \mathrm{mg}$ ) was extracted with $6 \mathrm{ml}$ of chloroform-methanol $(2: \mathrm{I}, \mathrm{v} / \mathrm{v})$ and centrifuged to remove insoluble cell debris. The chloroform-methanol fraction was partitioned with $3 \mathrm{ml}$ of $0.9 \%(\mathrm{w} / \mathrm{v}) \mathrm{NaCl}$. The resulting chloroform-soluble fraction was dried under nitrogen and dissolved in a known volume of hexane. The hydrocarbon was identified and quantified by gas-liquid chromatography with a Packard gas chromatograph, series 7500 , using a $20^{\circ}$ "diethyleneglycol succinate column. Operating conditions were: column temperature, $115 \mathrm{C}$ for hexadecane and naphthalene, and $105{ }^{\circ} \mathrm{C}$ for tetradecane; detector temperature, $190{ }^{\circ} \mathrm{C}$; injection temperature, $180^{\circ} \mathrm{C}$; outlet temperature, $205^{\circ} \mathrm{C}$; argon flow rate, $50 \mathrm{ml}$ $\min ^{-1}$; chart speed, $5 \mathrm{~min} \mathrm{in}^{-1}$ for naphthalene and $2.5 \mathrm{~min} \mathrm{in}^{-1}$ for the paraffinic hydrocarbons. Peak areas were determined by multiplication of peak heights by retention time, and concentrations were expressed as nmol hydrocarbon per mg dry cell weight or per o.0 I g wet weight for the Pseudomonas sp. and C. tropicalis. Each hydrocarbon was quantified by using a reference standard curve.

Poly- $\beta$-hydroxybutyric acid analysis. Hydrocarbon-grown organisms were extracted for poly- $\beta$-hydroxybutyric acid (PHB) according to the procedure of Williamson \& Wilkinson (I958). A known quantity of lyophilized cells was suspended in $25 \mathrm{ml}$ of commercial sodium hypochlorite solution (Chlorox) and incubated in a water bath at $37^{\circ} \mathrm{C}$ for $2 \mathrm{~h}$. The cell suspensions were centrifuged for $\mathrm{I} h$ at $17000 \mathrm{~g}$ at room temperature. The resulting cell pellets were suspended in distilled water (final $\mathrm{pH} 8 \cdot 0$ to 8.5) and centrifuged at $3500 \mathrm{~g}$ for $30 \mathrm{~min}$. The process was repeated, using $10 \mathrm{ml}$ of acetone followed by $10 \mathrm{ml}$ of absolute ethanol. The residue was dried under a stream of nitrogen and extracted with hot chloroform. The solution was filtered through Whatman $3 \mathrm{MM}$ filter paper and dried under a stream of nitrogen. PHB was assayed according to the procedure of Law \& Slepecky (196I). Concentrated $\mathrm{H}_{2} \mathrm{SO}_{4}(10 \mathrm{ml})$ was added to the sample and heated for $10 \mathrm{~min}$ at $100{ }^{\circ} \mathrm{C}$. The $E_{235}$ was measured against a sulphuric acid blank, after cooling and thorough mixing. The amount of crotonic acid was calculated from the molar extinction coefficient of $1.55 \times \mathrm{IO}^{4}$. As a positive control, PHB was also extracted and quantified in Bacillus megaterium strain KM grown in the medium of Macrae \& Wilkinson (1958).

\section{RESULTS}

A thin section of a Pseudomonas species grown in the presence of naphthalene vapours as a sole carbon and energy source is shown in Fig. I $(a)$. The naphthalene-grown cells contained electron-transparent inclusions but were otherwise similar in appearance to NBYE-grown cells (Fig. I $b$ ). The presence of electron-transparent inclusions is not peculiar to cells grown on long-chain paraffinic or olefinic hydrocarbons as demonstrated in Acinetobacter sp. strain HO I-N, but also results from growth on this polynuclear aromatic hydrocarbon.

The growth of two Gram-positive coryneform bacteria, an Arthrobacter sp. (Fig. 2a) and a Corynebacterium sp. (Fig. $3 a$ ), in the presence of hexadecane resulted in the appearance of electron-transparent inclusions. The Arthrobacter sp. contained unusually large inclusions which often appeared to be membrane-bound (Fig. $2 a$ ). These micro-organisms did not 

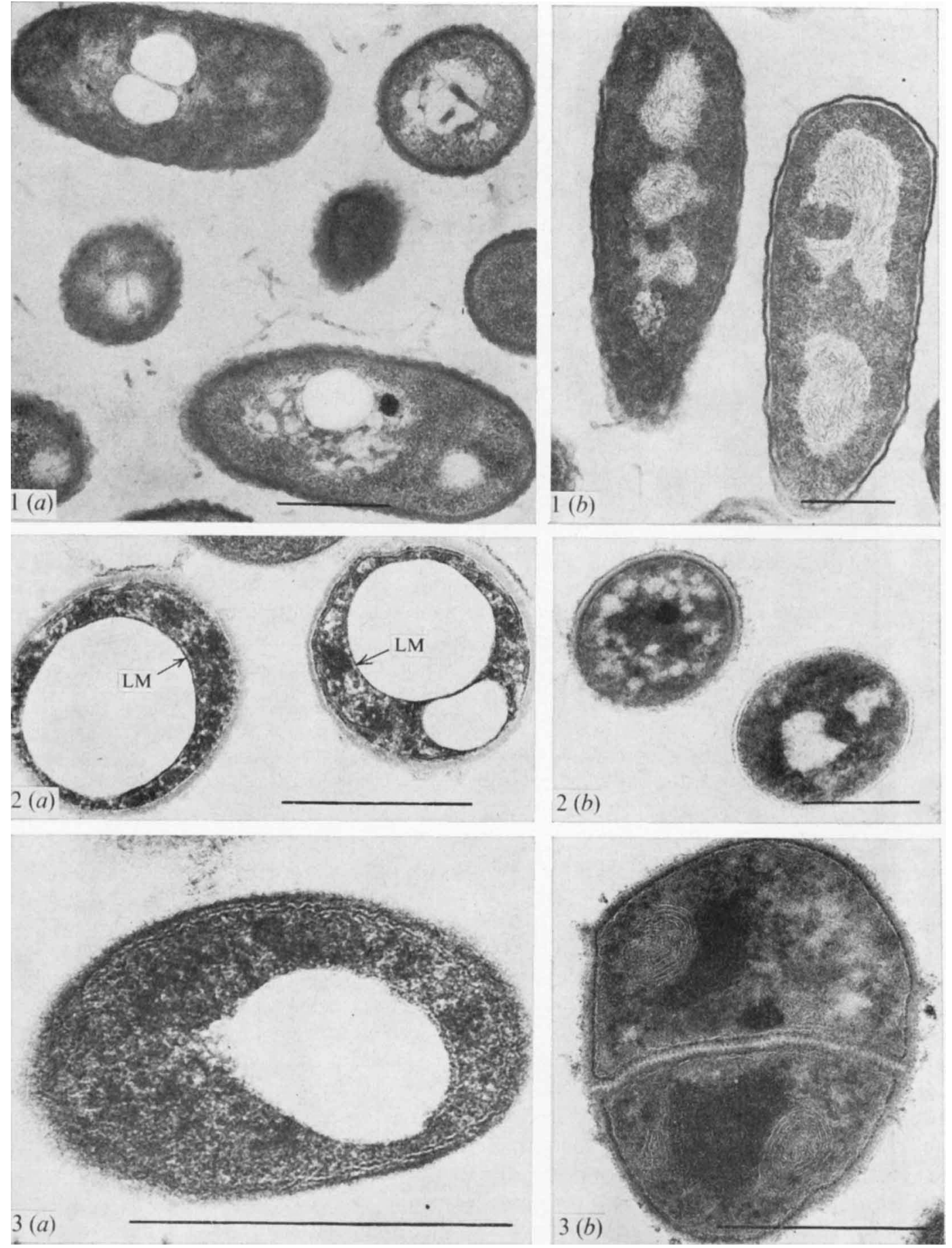

Fig. I. Thin section of $P_{\text {seudomonas }}$ sp. strain NP grown on (a) naphthalene vapours and (b) NBYE. Bar markers represent $0.5 \mu \mathrm{m}$.

Fig. 2. Thin section of Arthrobacter sp. strain 80 grown on (a) hexadecane and (b) NBYE. LM, limiting membrane of inclusion. Bar markers represent $0.5 \mu \mathrm{m}$.

Fig. 3. Thin section of Corynebacterium sp. grown on (a) hexadecane and (b) NBYE. Bar markers represent $0.5 \mu \mathrm{m}$. 
Table 2. Cellular hydrocarbon and $P H B$ in the hydrocarbon-grown micro-organisms

\begin{tabular}{|c|c|c|c|}
\hline \multirow[b]{2}{*}{ Organism } & \multicolumn{2}{|c|}{$\begin{array}{l}\text { Cellular hydrocarbon } \\
\text { (nmol/mg dry wt) }\end{array}$} & \multirow[b]{2}{*}{ PHB } \\
\hline & Liquid* & Plate† & \\
\hline Acinetobacter sp. HOI-N & 130 & 5 & 0 \\
\hline Pseudomonas sp. NP & $8+$ & - & 0.23 \\
\hline Arthrobacter sp. 80 & - & 60 & 0 \\
\hline Corynebacterium sp. & - & 9 & 0.06 \\
\hline Mycobacterium album 7E4 & 72 & - & $4 \cdot 3$ \\
\hline M. vaccae, јов5 & - & I 2 & 0.54 \\
\hline Nocardia sp. 72 & - & I & 0.07 \\
\hline Nocardia rubra & - & 13 & 0.05 \\
\hline Candida lipolytica Phaff & 390 & - & 0.24 \\
\hline C. tropicalis & $32+$ & - & 0.12 \\
\hline Bacillus megaterium $\mathrm{KM}$ & 二 & - & $410 \cdot 0$ \\
\hline
\end{tabular}

* The organisms were grown in a basal salts medium containing the liquid hydrocarbon.

$\dagger$ The organisms were grown on a basal salts agar plate in the presence of hydrocarbon vapours.

‡ Intracellular hydrocarbon, expressed as nmol hydrocarbon per $0 \cdot 0 \mathrm{r} g$ wet wt cells.

possess electron-transparent inclusions when grown on a NBYE medium (Figs. $2 b, 3 b$ ). Similar results were obtained with two genera of proactinomycetes. Numerous inclusions were evident in two species of Mycobacterium (Figs. $4 a, 5 a$ ) and in two species of Nocardia (Figs. $6 a, 7 a$ ) as a result of growth in a basal salts medium containing hexadecane. In some cases, the inclusions in these organisms also appeared to be membrane-bound (Figs. $4 a$, $5 a, 7 a$ ). Nocardia rubra (Fig. $6 b$ ) did contain electron-transparent inclusions when grown on a non-hydrocarbon substrate. However, this organism was shown to contain PHB ( $3.12 \mathrm{nmol} / \mathrm{mg}$ dry cell weight) when grown in NBYE which may account for the presence of these inclusions. This organism produced an insignificant amount of PHB when grown on hexadecane (Table 2). Mycobacterium album (Fig. $4 b$ ), $M$. vaccae (Fig. $5 b$ ), and the other Nocardia sp. (Fig. $7 b$ ) did not contain electron-transparent inclusions when grown on a non-hydrocarbon substrate. Both species of Nocardia contained electron-dense bodies as a result of growth on hydrocarbon and non-hydrocarbon substrates.

Two species of the yeast Candida were characterized by the presence of electron-transparent inclusions after growth on a hydrocarbon substrate (Figs. $8 a, 9 a$ ). These inclusions were not present in cells when grown in NBYE medium (Figs. $8 b, 9 c$ ). Cultivation of $C$. lipolytica in a basal salts medium containing hexadecane resulted in the presence of large electron-transparent inclusions within the cytoplasm (Fig. 8a). Candida tropicalis grown in the presence of tetradecane vapours contained smaller inclusions, mainly localized around the periphery of the cell (Fig. 9a). Higher magnification revealed that these inclusions were localized on the exterior surface of the cytoplasmic membrane (Fig. $9 b$ ). Occasionally, an inclusion could be seen within the cytoplasm (Fig. 9a). Generally, both species had thicker, less electron-dense cell walls when grown on the hydrocarbon substrates.

If the micro-organisms were sequestering hydrocarbons, as indicated by the presence of electron-transparent inclusions in the cells, detectable amounts of the hydrocarbon growth substrate should have been present in the cells. Consequently, chloroform-methanol extracts of the various hydrocarbon-grown organisms were analysed by gas-liquid chromatography for the respective growth hydrocarbon (Table 2). All of the chloroform extracts of the hydrocarbon-grown micro-organisms were found to contain the growth hydrocarbon after extensive washing of the cells. Some of the micro-organisms exhibited a tendency to float, even after centrifugation at $27000 \mathrm{~g}$ for $30 \mathrm{~min}$, after growth on the hydrocarbon substrate. 

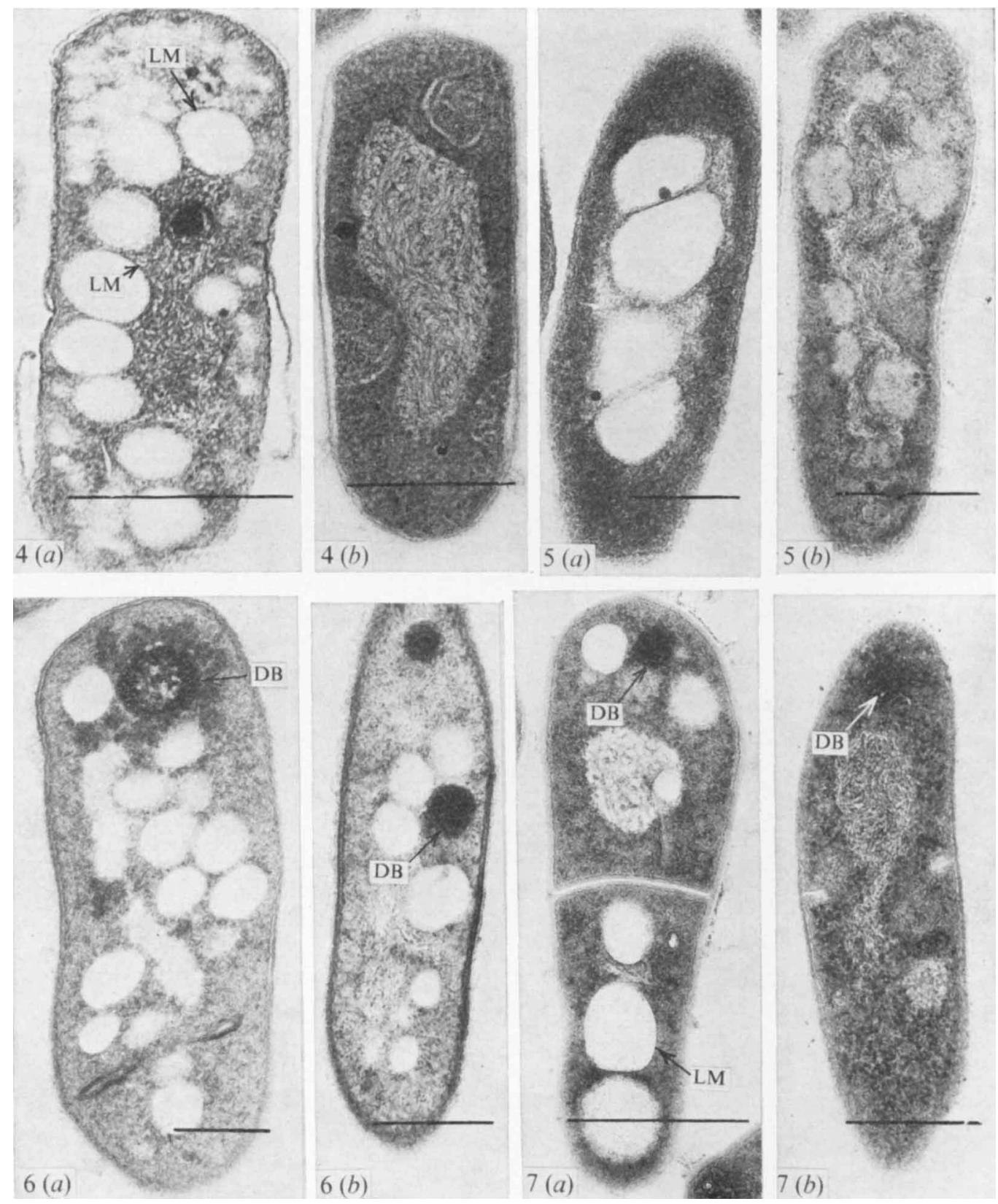

Fig. 4. Thin section of $M$. album strain 7E4 grown on (a) hexadecane vapours and (b) nutrient agar. $\mathrm{LM}$, limiting membrane of inclusion. Bar markers represent $0.5 \mu \mathrm{m}$.

Fig. 5. Thin section of $M$. vaccae strain JOB5 grown on (a) hexadecane and $(b)$ NBYE. Bar markers represent $0.2 \mu \mathrm{m}$ for $(a)$ and $0.5 \mu \mathrm{m}$ for $(b)$.

Fig. 6. Thin section of $N$. rubra grown on (a) hexadecane and (b) NBYE. DB, dense bodies. Bar markers represent $0.5 \mu \mathrm{m}$.

Fig. 7. Thin section of Nocardia sp. strain 72 grown on $(a)$ hexadecane and $(b)$ NBYE. LM, limiting membrane of inclusion. DB, dense bodies. Bar markers represent $0.5 \mu \mathrm{m}$. 
Therefore these organisms were analysed for hydrocarbon after growth on a basal salts agar plate in the presence of hydrocarbon vapours. These cells could be removed from the surface of the agar plate and washed by repeated centrifugation as described for cultures grown in direct contact with liquid alkanes. Acinetobacter has been shown to pool hydrocarbons when grown with either hexadecane vapours or in direct physical contact with liquid hexadecane, resulting in the presence of electron-transparent inclusions (Kennedy et al., 1975) Growth of Acinetobacter in the presence of vapours does, however, result in lower concentrations of the hydrocarbon.

Bacteria which produce PHB contain electron-transparent inclusions very similar in appearance to the inclusions observed in this study (Dunlop \& Robards, 1973). Consequently, all the organisms were tested for their ability to produce PHB when grown on hydrocarbons (Table 2). As a positive control, PHB was quantified in Bacillus megaterium strain KM, an organism known to produce PHB under the growth conditions employed (Williamson \& Wilkinson, 1958). Compared with this organism, most of the hydrocarbon oxidizers produced insignificant amounts of PHB. Mycobacterium album did contain a relatively higher amount of $\mathrm{PHB}$ as compared with the other hydrocarbon-grown microorganisms.

\section{DISCUSSION}

Some bacteria form cellular reserve materials which appear as electron-transparent inclusions in thin sections (Shively, 1974). These include glycogen, lipids and PHB. The possibility that the inclusions were PHB has been eliminated, except with $M$. album which appears to produce a small amount of PHB when grown on hexadecane. Glycogen granules appear as small (20 to $100 \mathrm{~nm}$ ) inclusions with diffuse outlines which generally accumulate as non-membrane-bound inclusions (Dipersio \& Deal, 1974; Shively, 1974). The inclusions characteristic of the hydrocarbon-grown organisms are larger and often have well-defined limits, suggesting the presence of a surrounding membrane. In addition to glycogen, certain species of Nocardia contain other larger electron-transparent inclusions thought to be composed of lipid (Dipersio \& Deal, 1974). Growth of a Nocardia species on hexadecane and octadecane has been shown to result in the formation of large amounts of cellular lipid, especially glycerides and straight-chain waxes (Raymond \& Davis, 1960). Consequently, the inclusions observed in the Nocardia species could partially represent accumulation of lipids other than hexadecane.

The fine structure of $C$. lipolytica has been described after growth on hydrocarbon and non-hydrocarbon substrates (Munk, Dostalek \& Volfova, 1969; Ludvik, Munk \& Dostalek, I968). Hexadecane-grown cells were said to contain a larger number of fat vacuoles, which were not positively identified. The hydrocarbon accumulated at the surface of the cytoplasmic membrane, as shown by a thin electron-transparent layer on the exterior surface of the membrane and by the localization of an electron-dense marker, vanadium naphthenate. In this study, $C$. lipolytica did not appear to accumulate hexadecane at the surface of the cytoplasmic membrane. Washed cells contained large amounts of cellular hexadecane (Table 2), suggesting the inclusions observed represented pools of the hydrocarbon. Candida tropicalis appeared to accumulate tetradecane at the surface of the cytoplasmic membrane in the form of small vesicles projecting into the cytoplasm. Occasionally, the vesicles appeared within the cytoplasm at the periphery of the cell, suggesting an endocytotic type of mechanism for hydrocarbon transport. This has been suggested by Ludvik et al. (1968), who observed pinocytotic vesicles at the ends of deep invaginations of the cytoplasmic membrane in hexadecane-grown cells of $C$. lipolytica. The vesicles observed in $C$. tropicalis resulted from growth in the presence of tetradecane vapours, indicating that direct contact of the 

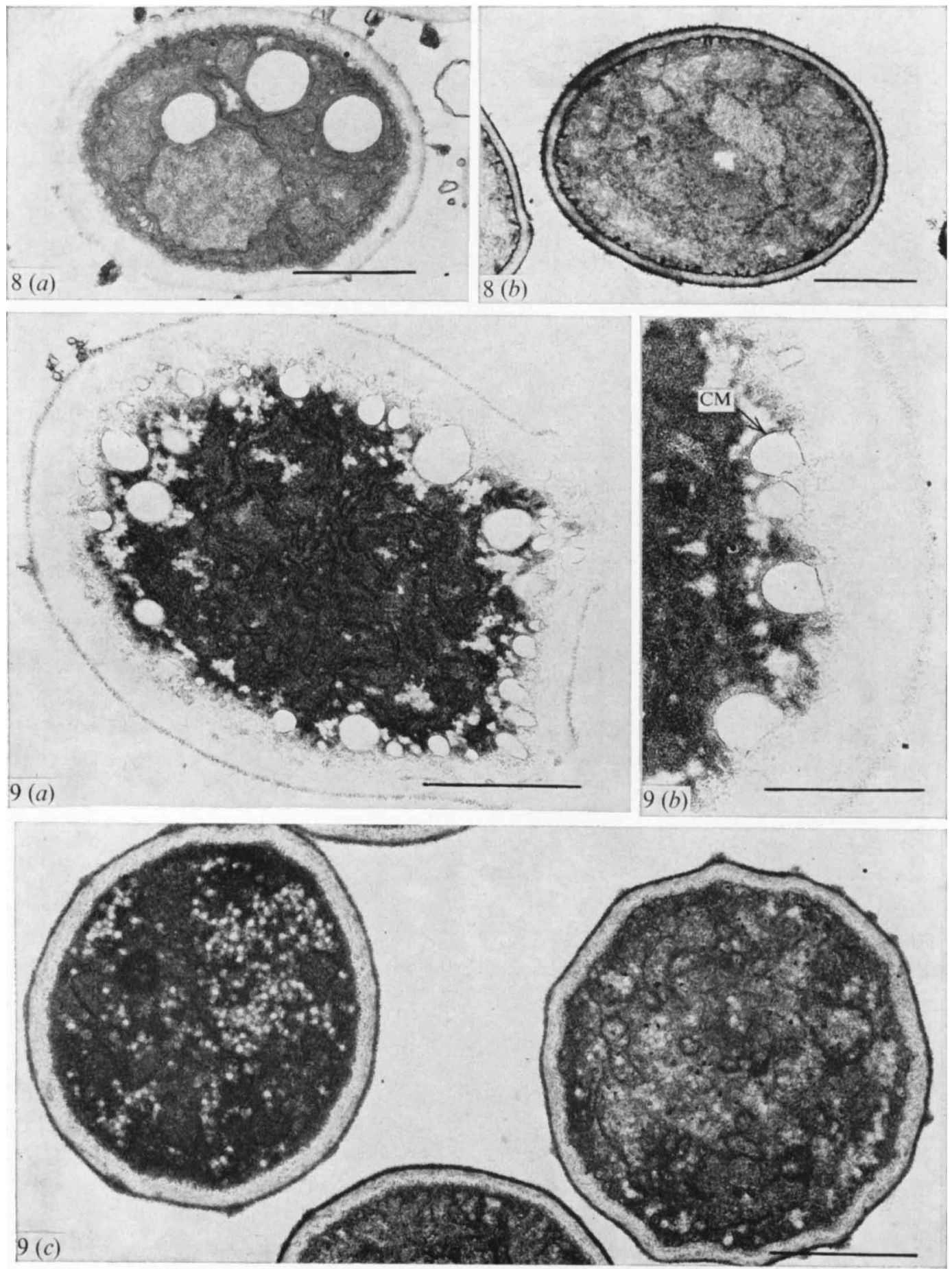

Fig. 8. Thin section of $C$. lipolytica grown on (a) hexadecane and $(b)$ NBYE. Bar markers represent $\mathrm{I} \cdot 0 \mu \mathrm{m}$.

Fig. 9. Thin section of $C$. tropicalis grown on $(a, b)$ tetradecane vapours and (c) NBYE. $\mathrm{CM}$, cytoplasmic membrane. Bar markers represent $\mathrm{I} \cdot 0 \mu \mathrm{m}$ for $(a), 0.5 \mu \mathrm{m}$ for $(b)$ and $\mathrm{I} \cdot 0 \mu \mathrm{m}$ for $(c)$. 
cell wall and the hydrocarbon droplet is not necessary as was previously suggested by Bos \& DeBoer ( 1968$)$.

Ultrastructural modifications and the sequestering of hydrocarbon, resulting from the growth on hydrocarbon substrates, appear to be generalized phenomena characteristic of a variety of bacteria and the yeast Candida. As discussed by Kennedy et al. (1975), this indicates a mechanism of transport for the hydrocarbons allowing for the intracellular accumulation of the unmodified hydrocarbon.

Cellular inclusions in bacteria have been classified into non-membrane-enclosed inclusions and membrane-enclosed inclusions (Shively, 1974). The membrane-enclosed inclusions appear to be limited by a non-unit type of membrane, with the hydrocarbon inclusions representing another example of this type of membrane structure. This aspect of the fine structure of hydrocarbon inclusions is currently under study in Acinetobacter sp.

These studies were supported by National Science Foundation grant GB-34I 20 to W. R. Finnerty. Appreciation is extended to the Electron Microscopy Laboratory of the University of Georgia for use of facilities.

\section{REFERENCES}

AtLAS, R. M. \& Heintz, C. E. (1973). Ultrastructure of two species of oil-degrading marine bacteria. Canadian Journal of Microbiology 19, 43-45.

Bos, P. \& DeBoer, W. E. (1968). Some aspects of the utilization of hydrocarbons by yeasts. Antonie van Leewvenhoek 34, 24I-243.

Davies, S. L. \& Whittenbury, R. (1970). Fine structure of methane and other hydrocarbon-utilizing bacteria. Journal of General Microbiology 6r, 227-232.

DEBoER, W. E. \& HAZEU, W. (1972). Observations on the fine structure of a methane oxidizing bacterium. Antonie van Leeuw'enhoek 38, 33-47.

Dipersio, J. R. \& DeAL, S. J. (1974). Identification of intracellular polysaccharide granules in thin sections of Nocardia asteroides. Journal of General Microbiology 83, 349-358.

DunLOP, W. F. \& Robards, A. W. (1973). Ultrastructural study of poly- $\beta$-hydroxybutyrate granules from Bacillus cereus. Journal of Bacteriology 114, $1271-1280$.

Kellenberger, E., Ryter, A. \& Sechaud, J. (I958). Electron microscopy study of DNA-containing plasms. II. Vegetative and mature phage DNA as compared with normal bacterial nucleoids in different physiological states. Journal of Biophysical and Biochemical Cytology 4, 67I-678.

KenNeDY, R. S. \& FinNerTY, W. R. (1975). Microbial assimilation of hydrocarbons. II. Intracytoplasmic membrane induction in Acinetobacter sp. Archives of Microbiology 102, 85-90.

Kennedy, R. S., Finnerty, W. R., Sudarsanan, K. \& Young, R. A. (1975). Microbial assimilation of hydrocarbons. I. The fine structure of a hydrocarbon oxidizing Acinetobacter sp. Archives of Microbiology 102, 75-83.

Kormandy, A. C. \& Wayman, M. (1974). Characteristic cytoplasmic structures in microorganisms utilizing $n$-butane and I-butanol. Canadian Journal of Microbiology 20, 225-230.

LAW, J. H. \& SlEPECKY, R. A. (196I). Assay of poly- $\beta$-hydroxybutyric acid. Journal of Bacteriology 82, 33-36.

Ludvik, J., Munk, V. \& Dostalek, M. (I968). Ultrastructural changes in the yeast Candida lipolytica caused by penetration of hydrocarbons into the cell. Experientia 24, 1066-1068.

LUFT, J. H. (1961). Improvements in epoxy resin embedding methods. Journal of Biophysical and Biochemical Cytology 9, 409-414.

MACRAE, R. M. \& Wilkinson, J. F. (1958). Poly- $\beta$-hydroxybutyrate metabolism in washed suspensions of Bacillus cereus and Bacillus megaterium. Journal of General Microbiology 19, 210-222.

Munk, V., Dostalek, M. \& Volfova, O. (1969). Cultivation of yeast on gas oil. Biotechnology and Bioengineering 21, 383-391.

Osumi, M., Fukuzumi, F., Teranishi, Y., Tanaka, A. \& Fukui, S. (1975). Development of microbodies in Candida tropicalis during incubation in a $n$-alkane medium. Archives of Microbiology ro3, I-II.

Raymond, R. L. \& Davis, J. B. (1960). $n$-Alkane utilization and lipid formation by a Nocardia. Applied Microbiology 8, 329-334.

REYNOLDS, E. S. (1963). The use of lead citrate at high $\mathrm{pH}$ as an electron-opaque stain in electron microscopy. Journal of Cell Biology 17, 208-21 2.

Shively, J. M. (1974). Inclusion bodies of procaryotes. Annual Review of Microbiology 28, I67-I 87.

Williamson, D. H. \& Wilkinson, J. F. ( 1958 ). The isolation and estimation of the poly- $\beta$-hydroxybutyrate inclusions of Bacillus sp. Journal of General Microbiology 19, 198-200. 